\title{
COMPOSITE INDICATORS AND SUSTAINABLE DE- VELOPMENT OF REGIONAL AGRICULTURE APPLIED TO THE STAVROPOL TERRITORY IN RUSSIA
}

\author{
Anastasia Chaplitskaya $^{1}$ - Wim Heijman ${ }^{2}$ - Johan van Ophem ${ }^{3}$ \\ ${ }^{1}$ Stavropol State Agrarian University, 12 Zootechnicheskiy Ln, Stavropol, 355037 \\ 1 anastasia.chaplitskaya@wur.nl \\ ${ }^{2,3}$ Wageningen University and Research, Hollandseweg 1, 6706KN Wageningen \\ ${ }^{2}$ wim.heijman@wur.nl, ${ }^{3}$ johan.vanophem@wur.nl
}

\begin{abstract}
The aim of this paper is to understand and evaluate agricultural sustainability in the Stavropol Territory by means of a composite indicator. In particular, the paper applies principal component analyses to calculate a composite sustainability index by integration of selected economic, social and environmental indicators. The results demonstrate the utility of analyzing several indicators in conjunction. The results also may indicate which variables influence development of regional agriculture. This information is important in order to design agricultural support policy and to implement an increase the sustainability of the agriculture sector.
\end{abstract}

Keywords: sustainability, composite indicators, principle component analysis, agricultural policy.

(JEL Code: O13, Q11)

\section{INTRODUCTION}

State regulation of agricultural development requires a systematic analysis of the states and trends of the industry, an assessment of the impact of the constantly changing business environment, and an identification of the possible positive changes and negative consequences. Such analysis is relevant for the industry in general and at the level of individual regions, wherein a considerable proportion of the agricultural sector occur. The Stavropol Territory accounts for a considerable proportion of the agricultural sector in Russia. Agriculture is important to the overall economic activity in the Stavropol Territory. There are about 300 large and medium sized agricultural enterprises, 15 thousand peasant (farmer) households and more than 400 thousand individual (subsidiary) farms in the Stavropol Territory.

The Stavropol Territory is a region in southern Russia. The total population as of 1 January, is 2799.5 thousand people, including 1627.5 thousand urban residents and 1172.0 thousand rural residents. The distance from Stavropol to Moscow is $1621 \mathrm{~km}$. It has a total of 62.2 thousand. The climate of the temperate zone is Atlantic continental in the north and mountain climate of the North Caucasus region in the south.

Stavropol Territory is one of the leaders of corn production in the Russian Federation. According to the Ministry of Agriculture of Stavropol Territory, the recent years have been quite positive. Its gross yield reaches 8.6 million tons per hectare under favourable weather conditions, but may decline in 1.7 times at the worst weather conditions. Wheat is the most important cultivated crop in the region and is responsible for $80 \%$ of the grain.

Crop production is the foundation for agribusiness in the Stavropol Territory. It provides feed for livestock and poultry, and raw material for processing plants that contributes to agribusiness sustainability.

Livestock production is also a contributor and socially important to the agricultural sector in the Stavropol Territory. Livestock production in the Stavropol Territory is ranked second for highest number of poultry and tenth for cow population and milk production out of all regions in the Russian Federation.

Historically the main specialization of sheep breeding was the production of fine wools in the Stavropol Territory. Its share in the turnover of the sub-sector's gross product reached $70-80 \%$. In 2016 production in the region reached 7.2 thousand tons of wool. The majority of that production comes from peasant farms $-(40.2 \%)$ and personal subsidiaries - (31.9\%). The Stavropol Territory takes second place among Russian regions in terms of wool production and exported wool to India, China and European countries, as well as supplying the needs of the domestic textile industry.

The role and importance of regional agriculture has increased. It performs an important function in meeting the 
Table 1. Agricultural production in Russia by region 2001-2015, for the top 10 regions for the year 2015, in billions of RUB (actual prices)

\begin{tabular}{|c|c|c|c|c|c|c|c|c|c|c|c|c|c|c|c|c|}
\hline & Region & 2001 & 2002 & 2003 & 2004 & 2005 & 2006 & 2007 & 2008 & 2009 & 2010 & 2011 & 2012 & 2013 & 2014 & 2015 \\
\hline 1 & $\begin{array}{l}\text { Krasnodar } \\
\text { region }\end{array}$ & 60.1 & 63.4 & 66.8 & 88.1 & 97.1 & 111.2 & 142.4 & 185.3 & 175.2 & 201.6 & 239.2 & 234.5 & 254.7 & 286.5 & 333.6 \\
\hline 2 & Rostov region & 34.8 & 36.6 & 41.3 & 56.9 & 61.5 & 67.6 & 79.7 & 115.8 & 102.4 & 118.1 & 149.0 & 154.7 & 161.3 & 191.3 & 229.3 \\
\hline 3 & Belgorod region & 19.5 & 19.6 & 22.9 & 26.4 & 32.7 & 39.1 & 56.3 & 75.7 & 86.5 & 98.1 & 134.6 & 149.3 & 155.4 & 188.2 & 218.1 \\
\hline 4 & $\begin{array}{l}\text { Republic of } \\
\text { Tatarstan }\end{array}$ & 39.4 & 39.0 & 44.9 & 53.7 & 61.6 & 71.6 & 93.5 & 117.3 & 116.5 & 100.8 & 150.4 & 150.1 & 160.2 & 186.0 & 213.7 \\
\hline 5 & Voroneg region & 22.1 & 23.2 & 28.8 & 29.3 & 31.7 & 35.9 & 52.9 & 69.0 & 75.3 & 68.2 & 101.5 & 125.5 & 143.9 & 158.9 & 200.2 \\
\hline 6 & Stavropol region & 24.5 & 26.6 & 30.8 & 41.5 & 44.5 & 50.6 & 69.1 & 76.4 & 67.7 & 84.3 & 103.5 & 101.2 & 122.8 & 149.0 & 175.7 \\
\hline 7 & $\begin{array}{l}\text { Republic of } \\
\text { Bashkortostan }\end{array}$ & 35.8 & 42.9 & 49.1 & 55.3 & 60.4 & 70.9 & 81.6 & 105.1 & 103.8 & 88.6 & 108.9 & 106.8 & 126.4 & 136.9 & 152.1 \\
\hline 8 & Altai Territory & 30.8 & 30.5 & 35.2 & 41.5 & 39.8 & 46.4 & 57.1 & 69.2 & 76.4 & 83.3 & 93.8 & 94.3 & 114.7 & 113.9 & 140.4 \\
\hline 9 & $\begin{array}{l}\text { Volgograd } \\
\text { region }\end{array}$ & 22.3 & 23.7 & 28.7 & 33.1 & 33.0 & 39.4 & 53.3 & 70.7 & 65.7 & 64.3 & 76.1 & 83.9 & 89.9 & 107.8 & 125.2 \\
\hline 10 & Tambov region & 12.5 & 13.2 & 15.7 & 16.3 & 18.5 & 21.3 & 28.3 & 35.6 & 37.4 & 36.6 & 52.0 & 60.0 & 72.3 & 93.5 & 124.2 \\
\hline & $\begin{array}{l}\text { Data Source: } \\
\text { Federal State } \\
\text { Statistics Service }\end{array}$ & & & & & & & & & & & & & & & \\
\hline
\end{tabular}

needs of the state in agricultural production, for domestic consumption and for export deliveries. Stavropol Territory became one of the top 10 regions in agricultural production turnover in 2015 (175.7 RUB billion) (Table 1).

Because of the importance of the Stavropol Territory agricultural sector, not only at the regional and country's development level, but also for worldwide supply, there is growing interest in the search for balance between socioeconomic development and the proper use of natural resources to pursue sustainable agricultural development in Stavropol Region.

Despite some positive trends in the development of agriculture in the Stavropol Territory, the sustainability of this economic sector is not achieved yet. Today, however, this sector of the national economy is undergoing significant difficulties associated with a reduction in the profitability of agricultural enterprises and, the lack of the rural resource potential, primarily land and labor. Despite the existence of regulations in the sector, e.g. Federal Law 'On the Development of Agriculture (Federal law 2015), the Federal target Program 'Sustainable Rural Development for 2014-2017 and for the period up to 2020 (Federal Target Program 2012) and others, it is necessary to enhance the state regulation of the industry, since the country's national security and social protection of the rural population are mainly depending on it. Existing problems can be largely solved by improving the tools and methods of regulation based on new scientific approaches in the finance and credit, information and consulting, and staffing directions of state regulation of agriculture. Directions of state support must be determined in the process of strategic planning of agriculture development at the regional level as a whole and at the level of individual enterprises to meet social objectives. At the same time the strategic management of the agricultural enterprises should be closely linked to programs of state support of the agricultural sector because there are not enough own sources.

This study aims to analyse the Stavropol region agricultural sector by considering economic, social and ecological dimensions. Each of the three dimensions is equal components for sustainable growth. They should not be considered separately and each must be integrated in developing a sustainability framework (von Hauff et.al, 2009). Hence the research question is how to assess agricultural sustainable development for the Stavropol Territory with a composite indicator which can be used to develop policies that are consistent with maximizing social welfare in the region and improving sustainability in the agricultural sector of the Stavropol Territory.

\section{LITERATURE REVIEW}

Over the last years, the concept of "sustainable economic development" has come into the international practice. The term was used in the report of the World Commission on Environment and Development (WCED, 1987) headed by the Prime Minister of Norway Gro Harlem Brundtland in 1987 and it became widespread after the United Nations conference on the Environment and Development in June 1992 in Rio de Janeiro. The formal definition for sustainable development was established.

The sustainable development seeks to meet the needs of the present generation without compromising the ability of future generations to meet their own needs, which means enabling people now and in the future, to achieve a satisfactory level 
of social and economic development and, human and cultural fulfilment, making at the same time, a reasonable use of land resources and preserving the species and natural habitats. (WCED 1987)

In a broad sense, sustainable development strategy aims to achieve harmony between people (with each other), society and nature.

Regarding the definition above, Elkington (1998) proposed the concept of the 'triple bottom line' of sustainability, which is the triangulation of People, Planet, Profit, and considers seven dimensions of transformation that must occur to achieve harmonization among economic factors, environmental quality and social justice. Environmental and social problems most severely affect the vulnerable population of developing countries; however, there is barely research available on these regions. (Seuring and Gold 2013)

The common concept of "sustainable economic development" is mostly used with respect to the entire national economy.

The problem of sustainability of agricultural production is significantly more complex than in other sectors of the economy. Most of the main areas of research concerning the sustainability of agriculture have traditionally focussed on refinement of measurement methods and the nature of yield fluctuations, the identification of synchronous and asynchronous fluctuations in gross output, construction of yield forecasts with variations in weather conditions and the development of methods of industrial risks insurance.

The stability of natural ecosystems characterizes stocks and annual growth of organic substance. In turn, the structure of production systems are a certain set of economic resources and their stability is dependent on the ratio of different elements, such as labour, technology and the organization of production. In this context, the sustainable development of individual companies creates objective prerequisites for sustainable development of the economy for the entire region. If considering the sustainability of development in the agricultural sector as a synchronous interaction between participants in the proceedings with nature and action of biological systems, where despite the impact of the external environment, the rational combination of resources and demand. In this case we can regard the sustainable development of the agrarian and industrial complex as the ability of subjects of this type of reproduction to maintain continuously and dynamically a rational proportion between the factors of agricultural production and the necessary rate of development in the context of the economic risks and uncertainties.

Definition of sustainable agricultural development

Based on the arguments above, it seems necessary to define the term sustainable economic development in relation to agriculture. The definition is:

Ensuring the sustainable development of the agrarian sector is reached by a balanced solution to the agrarian economic and social problems of agricultural development whilst avoiding the destruction and reduction of its natural resource potential. This along with maintaining and improving the enabling environment, - and meeting the needs of present and future generations of people in agricultural production, primarily in environmentally safe foods.

\section{METHOD OF ANALYSIS}

There have been some Russian studies about the theoretical basis of diagnosis and evaluation of the agricultural sector's development. They are presented by Afanasev and Uzbashev (1996), Boyko (1986), and Zagaytov (1999). Models to increase economic sustainability of agricultural production are described by Granberg (2007). The systematic approach to the study of regional features of the agricultural sector as a whole has been used by Petrikova (2009), Korobeynikov (2011), Jakobsson et al. (2012), Emelynova et al. (2015) and others. Despite the presence of scientific and practical achievements in the field of sustainable development of the agrarian sector, further clarification and systematic study is needed. There is no uniform approach for the selection of criteria and indicators which allow to obtain reliable estimates about sustainability.

B ased on the existing research literature about sustainable development of Russian agriculture, few studies are found on evaluation of agricultural sustainability for the Stavropol Territory as a whole and evaluation of its municipality's evaluation is even rarer.

A nalysis of objectives, criteria and guidelines for the sustainable development of agriculture shows that it is characterized multiple objectives, multiple criteria and a number of uncontrollable fundamental factors of different natures. . A specific feature of sustainable development is a complex web of interaction and very diverse factors in the technological, environmental, economic and social fields. In this case it has been suggested to analyse agricultural sustainability by aggregating this multidimensional set of indicators into a single composite indicator. This approach has been used by Stockle et al. (1994), A ndreoli and Tellarini (2000), Sands and Podmore (2000), Riesgo and Gomez-Limon (2005, 2006), and Gomez-Limon and Riesgo (2009). At the same time, the evaluation methods of sustainable devel opment of agriculture at the regional level are still not shaped. Thus, the need for solving regional problems of sustainable devel opment, the lack of methodological basis of modeling in this area determines the rel evance of the topic of the research. The research results can be used to support consistence policies which maximizes social welfare in the region and which indicates the potential improvements of sustainability in the agriculture of the Stavropol Territory.

The main principles of the composite indicators method is the basis for the development of a system of indicators of sustai nable development of agriculture. It allows us to explore the major trends of sustainable development of the socioeconomic system as a whole. Unfortunately, the use of the composite indicators method to study the sustainability of agriculture development at the regional level is still in an early stage. The effectiveness of state regulation of the agrarian sector both at the federal and at the regional level requires a systematic evaluation of the results, resulting in choosing the most rational course of action. 
Various methods for cal culating a composite indicator are in existence. L ast-mentioned efforts include the development of headline indicators, aggregate indices, goal-oriented indicators, and green accounting system. Some initial composite indices were M easure of E conomic W elfare (M EW) by Nordhaus and Tobin (1973), I ndex of Social Progress (ISP) by Estes (1974), Physical Quality of Life Index (PQLI) by M orris (1979), and E conomic A spects of Welfare (EAW) by Zolotas (1981) and Brekke (1997).

In the 1990s other indices appeared for measuring the aggregate performance of the economy or sustainability, e.g. Human Development Index (HDI) by the United Nations D evelopment Programme (U NDP, 1990), Sustainable Progress Index (SPI) by K rotcheck and Narodoslawsky (1994), Index for Sustainable Economic Welfare (ISEW) by Daly and Cobb (1989), Barometer of Sustainability by International Union for Conservation of Nature and Natural Resources International Development Research Center (IUCN-IDRC, 1995).

Some of the most recently developed indices include the Compass of Sustainability by At Kisson (2005), and Environmental Sustainability Index (ESI) by Yale University's Center for Environmental Law and Policy in collaboration with Columbia University's Center for International Earth Science Information Network (CIESIN), and the World Economic Forum (2005).

Indicators and composite indicators are increasingly recognised as a useful tool for policy making and public communication in conveying information on countries' performance in the field such as environment, economy, society, or technological development (Singh et al., 2007)

The main difficulty in measuring and monitoring agricultural sustainability is that it is a dynamic rather than statistic concept and needs a high level of observation, such as at the national level. Whereas most agricultural scholars believe that measuring sustainability at the farm level is the most precise method, policies at higher levels (such as national) are increasingly affecting policies at lower levels (such a farm). It is necessary to understand the interaction between all levels because each level finds its explanation of mechanism in the level below, and its significance in the levels above (Hayati et-al., 2011).

Official methods of evaluating the effectiveness of Russian agriculture are represented in the annual national report on the results of implementation of "State Program on development of agriculture and regulation of agricultural products, raw materials and food for 2013-2020" (Russian Government, 2012). This report essence is to compare its data with theoretically achieved agriculture performance during the reporting period in the context of priorities put forward by the program. Official methods do allow tracing rational expenditures of budgetary funds, which, in turn, are reflected in the dynamics of the main socio-economic indicators of the country's agriculture and each constituent entity of the Federation individually.

The practical significance of the research is to develop a methodology that can simplify the assessment procedure of sustainability of the agriculture sector at the regional level by considering a multidimensional perspective. The study's results will demonstrate the advantages and disadvantages of various methods used to construct composite sustainability indicators (CSIs) demonstrating the usefulness of analyzing several of these indicators in order to obtain more robust results. The results demonstrate the utility of analyzing several indicators in conjunction. The results also may indicate which variables influence development of regional agriculture. This information is important in order to design agricultural support policy and to implement an increase the sustainability of the agriculture sector.

\section{SELECTION OF SUSTAINABILITY INDICATORS}

An analysis of sustainable development publications led to the conclusion that the greatest difficulty is the formation of indicators of sustainable development at the regional and municipal level.

Since previous studies have used a wide range of variables in their models, it should be taken into account that indicators need to be country, regional and farm specific. Indicators also depend on the development stage of the region and the intended use of the CSI ( QIU Hua-Jiao et. al. 2005).

We proposed a complete set of indicators for agricultural sustainability assessment at the regional level in the Stavropol Territory conceptualizing the effects of the current economic situation, on the basis of sustainable agriculture principals which are mentioned in the Federal Law 'On the Development of Agriculture (Federal law, 2015), the Federal target Program 'Sustainable Rural Development for 2014-2017 and for the period up to 2020 (Federal Target Program, 2012) and literature review (Table 2).

Table 2. Indicators for measuring agricultural sustainability

\begin{tabular}{|l|l|c|}
\hline $\begin{array}{l}\text { Type of } \\
\text { dimension }\end{array}$ & Indicator & $\begin{array}{c}\text { Unit of } \\
\text { measurement }\end{array}$ \\
\hline Economic & $\begin{array}{l}\text { Agricultural Gross Domestic } \\
\text { Product(AGRGDP) }\end{array}$ & RUB \\
\hline & Land productivity (LANDPROD) & RUB/ha \\
\hline & Labor productivity (LABOURPR) & $\begin{array}{c}\text { RUB per } \\
\text { capita }\end{array}$ \\
\hline Environmental & Organic fertilization (FORGANIC) & tonn \\
\hline & Soil cover for agriculture (SOIL) & ha \\
\hline Social & $\begin{array}{l}\text { Emissions of most air pollutants from } \\
\text { stationary sources (EMAIRPOLL) }\end{array}$ \\
\hline & $\begin{array}{l}\text { Proportion of rural population } \\
\text { (RURALPOP) }\end{array}$ & $\%$ \\
\hline & $\begin{array}{l}\text { Share of rural and residents' income } \\
\text { (WAGESHARE) }\end{array}$ & $\%$ \\
\hline
\end{tabular}

\section{Composite Sustainability Index (CSI).}

The main principle of CSI is aggregation of a combination of multidimensional indicators to formulate a composite indicator. It is a very flexible approach because multiple measurements are summarized for ease of interpretation and comparison. The data requirement is a range of measurements 
based on the set of selected indicators (Rigby et al., 2001).

Composite indicators are highly recognized as a useful tool for policy making and public communication in passing on information on countries' and regions' performance in various fields, such as environment, economy, society or technological development.

There are five methodological issues for CSI creation (Gomez-Limon and Riesgo, 2009):

- selection of the all the variables to be used in the CSI;

- multivariate analysis

- normalization of each of these variables;

- assigning weights to each variable which reflect that variable's contribution to that particular dimension of sustainability;

- aggregation of these normalized values to create the multi-dimensional CSI;

- presentation of the CSI.

A composite indicator is based on sub-indicators that have no common meaningful unit of measurement and there is no obvious way of weighting these sub-indicators (Singh et al., 2008). Each sub-indicator has to be relevant to the phenomenon to be measured. In our case it is sustainable development of agriculture. All sub-indictors have to be presented by high quality data. In some cases it may be necessary to drop some data points or to construct some missing ones. For repairing any gaps in the data, mean substitution or correlation results methods could be applied.

For the first stage of selection of all the variables to be used in the CSI (1), information was complete for 10 years of observations (2005-2014) within three dimensions (economic, social and environmental). Thus, there are no gaps in the data.

Before the second stage (3), it is necessary to perform a statistical test to check that there is no significant correlation between indicators within the selected base of indicators, i.e., to avoid double counting in the aggregation stage. Also, it is necessary to identify groups of indicators that are statistically similar, in order to simplify interpretation of the results (Gomez-Limon and Riesgo, 2009). We implemented Principle Component Analysis, which is used to assess relationships between the sub-indicators. In order to eliminate the impact of different sub- indicators within each dimension and for further aggregation of indicators, there is a need to normalize the indicator data (3), because they usually have different measure units. Many techniques for normalizing the indicators exist in the literature. We have chosen the re-scaling in a range $[0$, 1] (Freudenberg, 2003).

$$
\operatorname{Min}-\max \quad I_{k j}=\frac{x_{k j}-\min \left(x_{k}\right)}{\max \left(x_{k}\right)-\min \left(x_{k}\right)}[0 ; 1],
$$

where $\mathrm{I}_{\mathrm{kj}}$ is normalised indicator for variable $k$ and year $i$,

After normalization the scores of indicators range between 0 (the worst value, meaning the least sustainable option) and 1 (the best value, corresponding with the most sustainable option). (Gomez-Limon and Riesgo, 2009).

\section{RESULTS}

\section{Multivariate analysis (2)}

The multivariate analyis consists of verifying the relationship between the variables and thus preventing the mistake of selecting random variables that do not maintain links among themselves, which may compomise the results of the research (OECD, 2008).

Multivariate analysis must be conducted before the construction of composite indicator in order to make the best methodological decision on the standardisation processes, weighting, and aggregation on the variables analyzed (OECD, 2008). The varialbles were analyzed statistically. To achieve this, a priciple component analysis was performed in order to summarize the amount of information in the origional set of variables and eliminate those that do not reduce the quality of information of the theoretical model (Schuschny and Soto, 2009).

The correlation matrix for variables introduced in Table 2 is presented in Table 3. The results of correlation matrix identified that all variables have an acceptable correlation cofficient (Table 3).

\section{Table 3. Principle component analysis (correlation)}

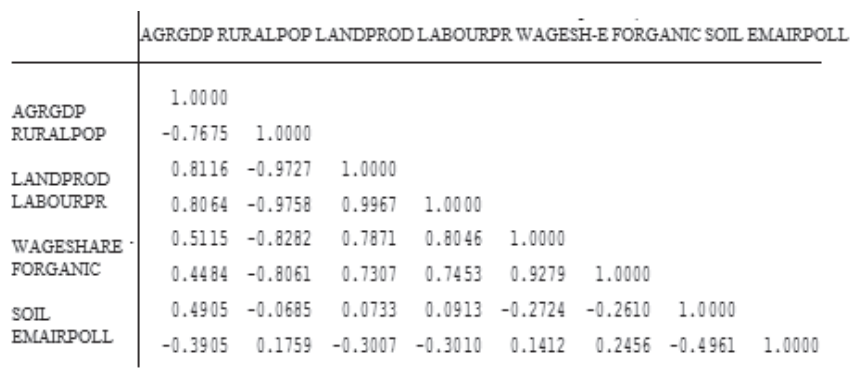

The estimation of the principle component analyses test shows that the KMO (Kaiser-Meyer-Olkin) coefficient has a value of 0.673 , which also exceeds the minimum acceptable value of 0.500 (Table 4).

Considering the variance explained, two main components can be built from the set of individual variables, which explains $88 \%$ of the variance.

Table 4. Extracted principle components

\begin{tabular}{|c|c|c|c|c|c|c|}
\hline \multirow[b]{2}{*}{ Component } & \multicolumn{3}{|c|}{$\begin{array}{l}\text { Extraction sums of squared } \\
\text { loadings }\end{array}$} & \multicolumn{3}{|c|}{$\begin{array}{l}\text { Rotation sums of squared } \\
\text { loadings }\end{array}$} \\
\hline & 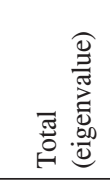 & 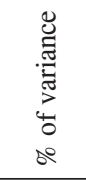 & 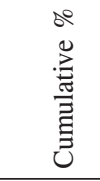 & 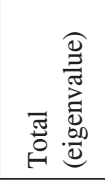 & 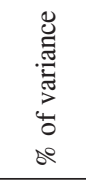 & 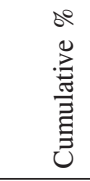 \\
\hline 1 & 5,035 & 62,93 & 62,93 & 4,974 & 62,17 & 62,17 \\
\hline 2 & 2,017 & 25,21 & 88,14 & 2,077 & 25,97 & 88,14 \\
\hline \multicolumn{5}{|c|}{ Kaiser-Meyer-Olkin measure of sampling adequacy } & 0.673 & \\
\hline
\end{tabular}

The criteria that support the choice of these two 
components was the Kaiser criterion which excludes variables with eigenvalues below 1 and accepts only variables with a variance higher than 1 .

The cumulative variance method considers $60 \%$ as a minimum percentage of variance explained for the social sciences is $60 \%$ (Garcia-Sanchez et.al, 2015). Therefore, two selected components are selected since they accumulated explain $88,14 \%$ of the information variance.

For understanding the meaning of these components, rotated factor loadings of the different indicators are analysed (Table 5). Table 5 illustrates the composition of the components formed from the combination of the variables. We blanked the loadings of indicators with greater than or equal to 0.3 in absolute value are in bold to indicate they are more significant. The data in Table 5 demonstrate that AGRGDP and FORGANIC are variables with high component loadings in more than one component simultaneously. In this context, the orthogonal rotation 'varimax' was executed to try to improve the results and make them clearer.

Table 5. Principal component analysis Rotated Component Loading

\begin{tabular}{|l|c|c|}
\hline & Component 1 & Component 2 \\
\hline AGRGDP & 0,738 & 0,561 \\
\hline RURALPOP & $-0,972$ & $-0,137$ \\
\hline LANDPROD & 0,956 & 0,226 \\
\hline LABOURPR & 0,962 & 0,226 \\
\hline WAGESHARE & 0,921 & $-0,285$ \\
\hline FORGANIC & 0,888 & $-0,349$ \\
\hline SOIL & $-0,056$ & 0,862 \\
\hline EMAIRPOLL & $-0,077$ & $-0,835$ \\
\hline Explained variance & 0.62 & 0.26 \\
\hline Proportion of Variance & 0.71 & 0.29 \\
\hline
\end{tabular}

Extraction method: Principle component analysis (Varimax rotation)

\section{Aggregation of indicators}

Once the principle components are extracted, the calculations of sub sustainability indicators $\left(S S I_{j i}\right)$ corresponding to each of the principle components $j$, are needed. This was done by calculating a weighted aggregation of indicators:

$$
S S I_{j i}=\sum_{k=1}^{k=n} w_{k j} I_{k i}(2),
$$

Where $S S I_{j i}$ is the sub sustainability indicator for the component $\mathrm{j}$ and the year $i$, the represents the weight of indicator $k$ in the component $\mathrm{j}$ and $w_{k j}$ is the normalized indicator $k$ achieved in the year $i$. The weights $w_{k j}$ are obtained from the factor loadings rotation matrix mentioned above by following the next expression:

$$
\mathrm{w}_{\mathrm{kj}}=\frac{\left(\text { factor_loading }_{\mathrm{kj}}\right)^{2}}{\text { eigenvalue }_{j}}
$$

Where factor_loading $g_{k j}$ is the value of the factor loading $\mathrm{k}$ in the principle component $\mathrm{j}$ (see Table 4), and eigenvalue ${ }_{j}$ is the eigenvalue of the jth principle component (see Table 5).

The weights of each indicator are showen in Table 6 . The weights are obtained from the priciple component analysis (PCA).

Table 6. Assigned weights for each component as determined by the principle component analysis

\begin{tabular}{|l|c|c|c|c|}
\hline & $\begin{array}{c}\text { Domain } \\
\text { weight }\end{array}$ & $\begin{array}{c}\text { Weight } \\
\text { of the } \\
\text { Respective } \\
\text { Component }\end{array}$ & $\begin{array}{c}\text { Weight } \\
\text { Score }\left(w_{i}\right)\end{array}$ & $\begin{array}{c}\text { Resulting } \\
\text { Weight } \\
\left(\Sigma \mathrm{w}_{\mathrm{i}}=1\right)\end{array}$ \\
\hline AGRGDP & 0.152 & 0.29 & 0.044 & 0.051 \\
\hline RURALPOP & 0.189 & 0.71 & 0.135 & 0.154 \\
\hline LANDPROD & 0.184 & 0.71 & 0.131 & 0.149 \\
\hline LABOURPR & 0.186 & 0.71 & 0.132 & 0.151 \\
\hline WAGESHARE & 0.171 & 0.71 & 0.121 & 0.138 \\
\hline FORGANIC & 0.158 & 0.71 & 0.113 & 0.128 \\
\hline SOIL & 0.358 & 0.29 & 0.104 & 0.118 \\
\hline EMAIRPOLL & 0.336 & 0.29 & 0.097 & 0.111 \\
\hline
\end{tabular}

Finally, the CSI can be calculated as a weighted aggregation of the sub sustainability indicators:

$$
\mathrm{CSI}=\sum_{j=1}^{j=2} a_{j} S S I_{j i}
$$

where CSI is the value of the composite indicator for the year $i$ and $a_{j}$ is the weight applied to the sub sustainability indicator $j$. These weights are calculated as follows:

$$
a_{j}=\frac{\text { eigenvalue }_{j}}{\sum_{j=1}^{j=2} \text { eigenvalue }_{j}}
$$

For the period from 2005-2014 the calculation of composite indicator of sustainable agricultural development was made and showed in Table 7 and Figure 1. Comparative data of sustainability indicator allows us to make a conclusion about the overall positive trends of sustainability in agricultural development. According to the calculation data show, the most auspicious year in terms of sustainability was 2014 .

Table 7. Results of agricultural CSI in the Stavropol Territory

\begin{tabular}{|c|c|}
\hline Year & Agricultural CSI \\
\hline 2005 & $-0,052$ \\
\hline 2006 & 0,133 \\
\hline 2007 & 0,107 \\
\hline 2008 & 0,264 \\
\hline 2009 & 0,175 \\
\hline 2010 & 0,187 \\
\hline 2011 & 0,269 \\
\hline 2012 & 0,289 \\
\hline 2013 & 0,365 \\
\hline 2014 & 0,545 \\
\hline
\end{tabular}


Figure 1. CSI of agricultural development in the Stavropol Territory

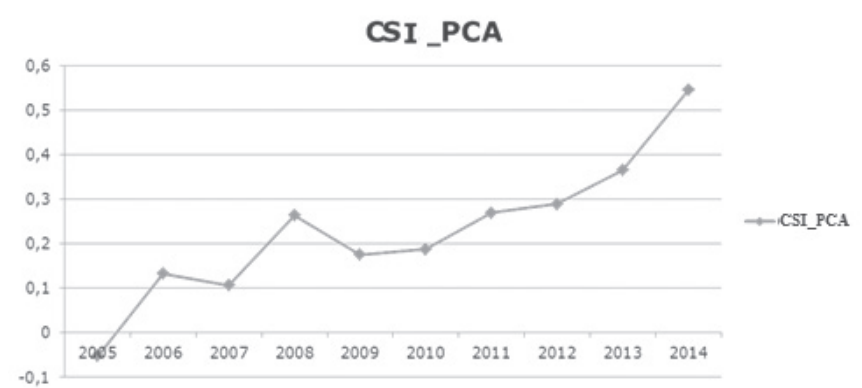

\section{CONCLUSION AND DISCUSSION}

For understanding the regional agriculture sustainability of the Stavropol Territory, this paper develops a comprehensive evaluation model of sustainability of agricultural development to calculate the score of agricultural sustainability in the that region in the period from 2005-2014. By using PCA analyses, this paper runs the regional evaluation of agricultural sustainability of the Stavropol Territory. The results show (Figure 1) that composite index of sustainable agricultural development changed over the past 10 years.

The results indicate highly positive dynamics of the composite indicator of agricultural development; however, a decline occurs from 2006 to 2007 and from 2008 to 2009. These declines are due not to the solvability of environmental problems and the sharp decline in the quality of life in the post-crisis period. Such as unsolved problems of utilization of production and consumption wastes, pollution of water objects, desertification of land, deterioration of the living facilities of citizens in rural areas, insufficient prosperity of rural residential areas and deterioration of the quality of medical and educational services.

Some weak areas were diagnosed, when we considered the changes of each indicator individually for the specified period. In spite of declines in the share of rural population in total population, sustainable development has a highly positive development trend (Figure 1). These declines are most likely due to internal and external migrations. The smaller share of population has higher effect on the number of farms and as a result more unused land. We recommend, as one of the best al ternative in terms of the sustainable development, creating supportive environment (legislation at the regional level) for the development of agro-tourism or rural tourism. Thanks to agro-tourism business, it may be driving-force for further sustainable development.

Despite the availability of data from Federal State Statistics Service, the present research has some limitations in number of indicators, especially for the environmental dimension, leading to a decrease in the variables regarded in the construction of composite index. This has also undoubtedly influenced the results, such that a complete picture of agricultural development cannot be provided. The data should be supplemented with other indicators. From the literature, the perception agricultural development has on the environment is that the consideration of environmental issues means higher cost and an ecosystem approach should be applied.
Future research should address the indicated limitations; it is important to collect data from other regions and perform analysis to see if the Stavropol region results are robust, e.g. compare results for the K rasnodar region to the Stavropol region in terms of economic and territorial position. Extension of the selection of variables in the analysis might be considered as well as the use of other methods of aggregation and weighting the base indicators for constructing the composite indicator, e.g. A nalytic Hierarchy Process (A H P) or Data Envelopment A nalysis (DEA).

The prospects of using this integrated approach of sustainability evaluation, as described in this paper, in the practice of managing the development of agriculture should be noted, because it allows:

- to give a quantitative description of the influence of individual factors on the development of agriculture;

- consider the impact of individual factors on agricultural development dynamics;

- to justify complex conditions for sustainable development of agriculture;

- use the data obtained to form a system of measures to ensure sustainable development of agriculture, which can be used in the process of making managerial decisions both at the regional and national levels.

\section{REFERENCES}

Afanas'ev VN., Uzbashev MM. (1996): Time series analysis and forecasting: Finance and Statistics, 1996: 336

Andreoli M. and Tellarini V., (2000): Farm sustainability evaluation: methodology and practice. Agriculture, Ecosystems and Environment, Vol. 77(1) pp.43-52. Permanent link to this documents: https://doi.org/10.1016/S0167-8809(99)00091-2

Boyko IP, (1986). Problems of sustainability of agricultural production. Leningrad: Leningrad State University, 1986:170

Brekke K A. (1997): Economic growth and the environment: on the measurement of income and welfare. Lyme, Cheltenham: Edward Elgar.

Daly HE., Cobb JB. (1989): For the Common Good: Redirecting the Economy Towards the Community, the Environment and a Sustainable Future. Boston.

Elkington J. (1998): Cannibals with forks - the triple bottom line of 21st century business. Gabriola Island: New Society Publishers, 1998.

Freudenberg, M. (2003) Composite indicators of country performance: a critical assessment. OECD, Paris

García-Sánchez IM, das Neves Almeida TA, de Barros Camara RP (2015): A proposal for a Composite Index of Environmental Performance (CIEP) for countries, Journal Ecological Indicators, Vol.48 pp. 171-188

Gomez-Limon, JA., Riesgo L. (2000): Alternative approaches on constructing a composite indicator to measure agricultural sustainability European Association of Agricultural Economists. 107th Seminar; 2008 Jan 30-Feb 1, Sevilla, Spain.

Gómez-Limón, JA., Riesgo L. (2009): Alternative approaches to the construction of a composite indicator of agricultural sustainability: an application to irrigated agriculture in the $\mathrm{Du}-$ 
ero basin, Spain Journal of Environmental Management, Vol. 90(11) pp.3345-3362. Permanent link to this documents: https:// doi.org/10.1016/j.jenvman.2009.05.023

Granberg AG. (2007): Basics of regional economics. Moscow: Epsom, 2007: 493.

Jakobsson C., Norrgren L., Karlsson I., Levengood J.(2012) Ecosystem Health and Sustainable Agriculture, Book 1: Sustainable Agriculture, The Baltic University Program, , Uppsala: Uppsla University Press, 2012:505

Korobeynikov DA. (2011): Methodological approaches to assessing the sustainability of regional agriculture. IL Vorotnikova, editor. Problems and prospects of sustainable agricultural development: materials of the International scientific-practical conference dedicated to the 80th anniversary of the Department of Economics and Organization of AIC; Saratov, 2011:144-149.

Emelyanova LL., Kropinova EG., Voloshenko KJ. (2015): The integrated approach to sustainable development of rural areas: the case for the agricultural sector in the Kaliningrad region of the Russian Federation Int. J. of Agricultural Resources, Governance and Ecology, Vol. 20 Iss 2, pp.158

Estes, R. (1974): A Comprehensive Corporate Social Reporting Model. Federal Accountant, pp. 9-20.

Federal Law (2015) On the development of agriculture, 12.02.2015, No. 11-FL. Legal information system 'Consultant - Plus'. Accessed on 10.10.2016, http://base.consultant.ru

Federal Target Program (2012) Sustainable Rural Development for 2014-2017 and for the period up to 2020, Decree of the Russian Federation of Nov 8, 2012, No.2071-p. Accessed on 10.10.2016, http://mcx.ru/documents/document/show/16518. htm

IUCN/IDRC (The World Conservation Union/International Development Research Center) (1995): Assessing progress towards sustainability: A new approach. In: Thadeus, Trzuna (Eds.), A Sustainable World: Defining and Measuring Sustainable Development. IUCN/IDRC, Sacramento, pp. 152-172.

Krotscheck C., Narodoslawsky M. (1994): The sustainable process index - a new dimension in ecological evaluation. Ecological Engineering, June.

Lockeretz W. (1998): Open questions in sustainable agriculture, American Journal of Alternative Agriculture, Vol. 3: pp.174181

Nardo M., Saisana M., Saltelli A., Tarantola, S. (2005b): Tools for composite indicators building. Joint Research Centre-European Commission, Ispra (Italy), 2005

Morris M D., Measuring the Condition of the World's Poor: The Physical Quality of Life Index .New York: Pergamum Press, 1979.

Nardo M., Saisana M., Saltelli A., Tarantola S., Hoffman A., Giovannini E. (2005a): Handbook on constructing composite indicators: methodology and user guide. OECD Statistics Working Paper. OECD, Paris, 2005

Nordhaus, William D. and Tobin J (1972): 'Is growth obsolete?' Economic Growth. 50th anniversary colloquium V. Columbia University Press for the National Bureau of Economic Research. New York. Reprinted in Milton Moss (ed.) 'The Measurement of Economic and Social Performance', Studies in Income and Wealth, Vol. 38, National Bureau of Economic Research, 1973.

OECD/EU/JRC (2008), Handbook on Constructing Composite Indicators: Methodology and User Guide, OECD Publishing, Paris.Permanent link to this document: http://dx.doi. org/10.1787/9789264043466-en

Petrikova AM (2009) Sustainable development of rural areas. Moscow: VIAPI named after. AA Nikonov, 2009: 272

QIU Hua-jiao, CHANG Xin, CHENG Xu and ZHU Wan-bin (2005). The Analysis and Design of Agricultural Sustainability Indicators System. Scientia Agricultura Sinica, 6(4): 475- 486. https://doi.org/ 10.1016/S1671-2927(07)60072-8.

Riesgo, L. and Gómez-Limón, J.A. (2005). Análisis de escenarios de políticas para la gestión pública de la agricultura de regadío. Economía Agraria y Recursos Naturales 5(9): 81-114.

Riesgo, L. and Gómez-Limón, J.A. (2006). Multi-criteria policy scenarios analysis for public regulation of irrigated agriculture. Agricultural Systems 91(1-2):1-28.

Rigby, D., Woodhouse, P., Young, T. and Burton, M. (2001). Constructing a farm level indicator of sustainable agricultural practice. Ecological Economics 39(3): 463-478.

Sands, GR. and Podmore TH. (2000). A generalized environmental sustainability index for agricultural systems. Agriculture, Ecosystems \& Environment 79(1):29-41

Seuring, S., Gold, S. (2013) Sustainability management beyond corporate boundaries: from stakeholders to performance, Journal of Cleaner Production 2013; 56: 1-6.

Schuschny A., Soto H.(2009) Guía metodológica diseño de indicadores compuestos de desarrollo sostenible Comisión Económica para América Latina y el Caribe (CEPAL), Naciones Unidas, Chile, 2009

Singh RK., Murty HR., Gupta SK., Dikshit AK. (2007): Development of composite sustainability performance index for steel industry, Ecological Indicators; 7(3):565-588.

State Program (2012) State Program for Development of Agriculture and Regulation of Markets of Agricultural Products, Raw Materials and Food for 2013-2020, Government Decree of 14.07.2012 No. 717. Accessed on 10.05.2016, http://government.ru/gov/results/19885/

Stockle C.O., Papendick R.I., Saxton K.E., Campbell GS., van Evert F.K. (1994): A framework for evaluating the sustainability of agricultural production systems, American Journal of Alternative Agriculture 1994; 9(1-2):45-50.

The state program of development of agriculture and regulation of the markets of agricultural production, raw materials and the food for 2013-2020 (2012). Accessed on 10.10.2016 http:// www.mcx.ru/documents/document/v7_show/16834.342.htm

United Nations Development Program, Human Development Report (1990): New York: Oxford University Press, various years.

von Hauff M., Kleine A. (2009) Sustainability in 3D - A Plea for Three Dimensions of Sustainability Nachhaltigkeit in 3D - Plädoyer für drei Nachhaltigkeitsdimensionen, GAIA 18/1: 29-31.

World commission on environment and development. (1987), Our common future. London: Oxford University Press, 1987:383.

Zagaitov IB., Ternovih KS., Korotchenkov VI., Kamalyan AK. (1999): Agribusiness Economics: General laws of development of agriculture. Voronezh: named after Bolkhovitinov EA., 1999: 287.

Zolotas, X. (1981): Economic growth and declining social welfare. New York: New York University Press 